\title{
PENINGKATAN PRESTASI BELAJAR MATEMATIKA DENGAN PENGGUNAAN METODE DISKUSI KELOMPOK KECIL PADA SISWA KELAS VI SEMESTER II SD NEGERI 2 PEGUYANGAN TAHUN PELAJARAN 2016/2017 Oleh
}

\author{
Ni Made Miasari \\ SD Negeri 2 Peguyangan \\ mademiasari1965@yahoo.com
}

\begin{abstract}
ABSTRAK
Tujuan pelaksanaan sebuah penelitian tindakan kelas adalah untuk menjelaskan proses pembelajaran yang dilakukan guru. Peningkatan tersebut akan mampu diupayakan lewat sebuah penelitian tindakan. Oleh karenanya penulis mencoba melakukan penelitian ini demi adanya upaya perbaikan tersebut.Tujuan tersebut lebih jelas lagi dan lebih terfokus lagi adalah untuk meningkatkan prestasi belajar anak. Penelitian ini mengambil objek pada kelas VI semester II SD Negeri 2 Peguyangan tahun pelajaran 2016/2017.Peningkatan prestasi belajar tersebut datanya diperoleh lewat pemberian tes, setelah data diperoleh, selanjutnya dianalisis menggunakan analisis deskriptif. Perolehan data hasil penelitian ini, ternyata menggembirakan setelah cara pembelajaran yang konvensional dirubah menggunakan metode diskusi kelompok kecil. Kegiatan penelitian ini menghasilkan suatu peningkatan yang diharapkan yaitu meningkatnya perolehan data awal yang baru mencapai 64,98 dengan ketuntasan belajar 25,00\% pada siklus I naik menjadi 67,87 dengan ketuntasan belajar 45,0\%. siklus II naik menjadi 74,10 dengan ketuntasan belajar 92,50\% Hasil tersebut membuktikan keberhasilan penelitian ini sehingga peneliti berkesimpulan bahwa penerapan metode diskusi kelompok kecil dalam pelaksanaan proses pembelajaran mampu meningkatkan prestasi belajar matematika siswa kelas VI semester II SD Negeri 2 Peguyangan tahun pelajaran 2016/2017.
\end{abstract}

\section{Kata Kunci: Metode Diskusi Kelompok Kecil ,Prestasi Belajar, Matematika}

\section{PENDAHULUAN}

Dunia pendidikan dewasa ini, tengah mendapat sorotan yang sangat tajam berkaitan dengan tuntutan untuk menghasilkan sumber daya manusia yang berkualitas, yaitu sumber daya manusia yang mampu "hidup" di abad ke-21 (Degeng, 2001:1). Pendidikan sebagai sumber daya insani sepatutnyalah mendapat perhatian secara terus menerus dalam upaya peningkatan mutunya. Peningkatan mutu pendidikan berarti pula peningkatan kualitas sumber daya manusia. Itulah salah satu harapan yang perlu menjadi perhatian para pendidik.

Harapan yang lain yang sulit untuk tidak dilaksanakan adalah tentang pendidikan kecakapan hidup. Menurut Sumiati dan Asra (2007: 183) pendidikan kecakapan hidup bertujuan mengembangkan potensi siswa sesuai dengan karakteristik, emosional, dan spiritual dalam prosfek pengembangan diri dalam menghadapi perannya di masa kini dan masa yang akan datang secara menyeluruh. Dengan kata lain, 
pendidikan kecakapan hidup bertujuan mengembangkan pengetahuan dan keterampilan yang dibutuhkan untuk bertahan dan meningkatkan kualitas hidup dalam semua lingkungan.

Rendahnya prestasi belajar merupakan fenomena yang terjadi di SD Negeri 2 Peguyangan . Pada saat melakukan observasi awal di kelas VI semester II diperoleh nilai rata-rata yang dicapai anak baru sebesar 64,98. Nilai tersebut belum memenuhi standar Kriteria Ketuntasan Minimal (KKM) mata pelajaran yang ditentukan sekolah ini yaitu 70,00. Melihat permasalahan tersebut, maka perlu dicarikan solusinya sehingga oleh peneliti dipandang perlu melakukan suatu penelitian tindakan kelas yang bertujuan untuk meningkatkan prestasi belajar Bahasa Indonesia dalam pembelajaran, guna meningkatkan pemahaman siswa tentang konsep diskusi kelompok kecil, dengan cara melibatkan anak secara aktif dalam pembelajaran, dan mendorong pembelajaran mandiri yang berpusat pada anak dan guru hanya sebagai fasilitator, motivator, pengaruh dan pembimbing.

Sebagai upaya memperbaiki mutu pendidikan utamanya pada mata pelajaran Bahasa Indonesia, alternatif tindakan yang dilakukan guru adalah perbaikan proses pembelajaran menggunakan metode diskusi kelompok kecil mengingat pemahaman bahwa setiap orang dilahirkan dengan rasa ingin tahu yang tinggi jika dikenalkan pada suatu yang baru. Yang harus dilakukan adalah proses penyampaian yang dilakukan harus dapat mengundang keinginan tersebut. Pembelajaran dengan menerapkan metode diskusi kelompok kecil merupakan salah satu model pembelajaran khususnya menyangkut keterampilan guru dalam melakukan proses pembelajaran yang didasarkan pada teori-teori para ahli. Akhirnya peneliti mencoba model ini dalam melaksanakan pembelajaran sebagai solusi dalam mengatasi masalah rendahnya prestasi belajar siswa kelas VI semester II SD Negeri 2 Peguyangan.

$\begin{array}{lrr}\text { Untuk } & \text { dapat } & \text { melaksanakan } \\ \text { pembelajaran } & \text { yang } & \text { berkualitas, } \\ \text { didahului } & \text { dengan } & \text { membuat }\end{array}$
perencanaan yang baik adalah upaya pemecahan masalah dalam penelitian ini.Dalam hal ini peneliti melakukan penggunaan metode diskusi kelompok kecil. Metode ini mempunyai langkahlangkah seperti: (1) penumbuhan minat siswa untuk beradu pendapat, (2) pemberian pengalaman langsung kepada siswa dalam menyajikan sesuatu karena mereka diajak untuk aktif mengeluarkan pendapat, (3) penyampaian materi dengan siswa berupaya sendiri meneliti materi untuk penguasaan yang lebih dalam, (4) adanya presentasi kemampuan bicara, (5) pengulangan oleh siswa untuk menunjukkan bahwa mereka benarbenar tahu, dan (6) penghargaan terhadap setiap usaha berupa pujian baik verbal maupun nonverbal, dorongan semangat. Cara inilah yang dapat digunakan sebagai dasar pemecahan masalah yang ada.

\section{METODE}

Lokasi yang dipilih untuk melakukan penelitian ini adalah SD Negeri 2 Peguyangan. Lingkungan sekolah yang bersih yang didukung dengan banyaknya tempat-tempat sampah sangat mendukung berlangsungnya proses pembelajaran yang baik dan lancar. Dalam penelitian ini penentuan subjek penelitian dimaksudkan untuk mendapatkan data 
yang dibutuhkan, yaitu nama siswa kelas VI semester II SD Negeri 2 Peguyangan tahun pelajaran 2016/2017, adapun objek penelitian ini adalah peningkatan prestasi belajar Matematika siswa kelas VI semester II SD Negeri 2 Peguyangan tahun pelajaran 2016/2017 setelah penggunaan metode diskusi kelompok merupakan objek penelitian. Pelaksanaan penelitian ini akan dilangsungkan dari bulan Januari sampai bulan Mei tahun 2017 selama 5 bulan. Teknik pengumpulan data merupakan cara kerja dalam penelitian untuk memperoleh data atau keterangan-keterangan dalam kegiatan sesuai dengan kenyataan. Teknik pengumpulan data yang digunakan dalam penelitian tindakan kelas ini adalah observasi dan tes prestasi belajar.

Data yang diperoleh dari hasil penelitian dapat dikelompokkan menjadi dua, yaitu data kualitatif dan kuantitatif. Dalam penelitian ini peneliti menggunakan analisis data kuantitaif. Data kuantitatif adalah data yang berbentuk angka.

Rancangan yang digunakan sebagai pedoman pelaksanaan penelitian ini adalah model Kemmis dan Mc. Taggart, dengan prosedur:

- Rancangan yang dibuat para ahli sangat penting dijadikan pedoman dalam melaksanakan penelitian. Prosedur pelaksanaannya tentu saja mengikuti alur rancangan para ahli. Dalam penelitian ini yang diikuti adalah rancangan atau gambar yang dibuat oleh Kemmis dan Mc. Taggart, sehingga prosedur yang diikuti adalah mulai dengan

- perencanaan, kemudian pelaksanaan, observasi dan refleksi. Selanjutnya bentuk spiral yang dibuat Kemmis berulang kembai mulai perencanaan, lanjut dengan pelaksanaan, observasi dan refleksi

Adapun kerangka berpikir yang dilakukan dalam tindakan pada siklus penelitian ini adalah diskusi kelompok kecil yang dengan sangat giat dilakukan melalui pengawasan guru agar peserta didik bisa bekerjasama dan bekerja bersama maka setiap materi yang disajikan disiapkan beberapa pertanyaan agar peserta didik bisa bekerjasama dalam timnya dan bekerja bersama untuk menyelesaikan tugastugas tertentu. Untuk bisa memenuhi tuntutan tersebut, penggunaan metode diskusi kelompok kecil sangat cocok untuk dicobakan mengingat metode tersebut merupakan sesuatu yang gampang untuk dikerjakan. Untuk ini guru harus betul-betul aktif mengupayakan perencanaan yang baik, memberi arahan-arahan, memberi tugas-tugas melalui persiapan yang matang. Keilmuan yang akan ditelorkan oleh siswa dituntun dengan baik oleh guru, diberi bimbingan, diberi penekanan-penekanan, diajak bekerja yang baik, berkolaborasi, bekerjsama dan bekerja bersama dan siswa dibiasakan untuk melakukannya. Dasar berpikir seperti inilah yang digunakan dalam pelaksanaan penelitian ini. Indikator keberhasilan penelitian dilihat dari ketuntasan belajar minimal $80,00 \%$ sangat diharapkan dalam penelitian ini. Apabila nilai siswa pada siklus I belum mencapai di atas KKM, akan dilanjutkan lagi pada siklus II agar mencapai rata-rata nilai di atas KKM dan ketuntasan melebihi $85,00 \%$.

\section{KAJIAN PUSTAKA \\ Prestasi Belajar}

Peneliti mengutip beberapa pernyataan dari para ahli untuk mendukung kebenaran teori yang disampaikan pada penelitian ini. $\mathrm{H}$. 
Abin Syamsuddin (2009) dalam buku psikologi kependidikan mendefinisikan prestasi atau hasil belajar peserta didik adalah: 1) daya atau kemampuan seseorang untuk berfikir dan berlatih ketikamengerjakan tugas atau kegiatan tertentu dan kegiatan pembelajaran di sekolah; 2) prestasi belajar tersebut terutama dinilai aspek kognitifnya (transferable) karena yang bersangkutan dengan kemampuan peserta didik dalam pengetahuan atau ingatan, pemahaman, aplikasi, analisis, sintesa, dan evaluasi; 3) prestasi belajar peserta didik dibuktikan dan ditunjukkan melalui nilai atau angka nilai dari hasil evaluasi yang dilakukan oleh guru terhadap tugas peserta didik dan ulangan-ulangan atau ujian yang ditempuhnya.

Prestasi belajar adalah penguasaan pengetahuan terhadap mata pelajaran yang dibuktikan melalui hasil tes yaitu penguasaan pengetahuan atau keterampilan yang dikembangkan oleh mata pelajaran, lazimnya ditunjukkan dengan nilai tes atau angka nilai yang diberikan oleh guru (Peter Salim, 1995:190).

Sutratinah Tirtonegoro (2001: 43) menyebutkan bahwa prestasi belajar adalah hasil dari pengukuran serta penilaian usaha belajar. Memberi batasan prestasi belajar yaitu hasil usaha kegiatan belajar yang dinyatakan dalam bentuk simbol-simbol, huruf atau kalimat yang sudah dicapai oleh setiap peserta didik dalam setiap periode tertentu

Berdasarkan pengertianpengertian menurut para ahli di atas, maka dapat disimpulkan bahwa prestasi belajar merupakan hasil atau tingkat kemampuan seseorang setelah melakukan proses belajar. Prestasi belajar seseorang sesuai dengan tingkat keberhasilan dalam mempelajari materipelajaran yang dinyatakan dalam bentuk nilai setiap mata pelajaran setelah mengalami proses belajar mengajar. Prestasi belajar siswa dapat diketahui setelah diadakan evaluasi. Hasil dari evaluasi dapat memperlihatkan tentang tinggi atau rendahnya prestasi belajar siswa.

Prestasi belajar setiap peserta didik berbeda-beda, hal ini sangat dipengaruhi oleh beberapa faktor yaitu: faktor indogen dan faktor eksogen. a) faktor indogen adalah faktor yang berasal dari dalam diri peserta didik. Faktor indogen dibagi menjadi dua yaitu faktor biologis dan faktor psikologis (Abu Ahmadi, 1982)) yang dikutif dari (Bhakti, 2009: 36). Faktor biologis antara lain kesehatan, kelengkapan panca indra, kelengkapan anggota badan atau tidak cacat. Faktor psikologis antara lain intelegensi, minat,bakat dan emosi. Faktor eksogen meliputi faktor lingkungan keluarga, lingkungan sekolah dan lingkungan masyarakat.Faktor-faktor tersebut sangat berpengaruh terhadap prestasi belajar peserta didik.

Tujuan belajar merupakan perubahan tingkah laku, hal ini dapat diidentifikasikan melalui ciri-ciri belajar, sebagaimana pendapat yang dikemukakan oleh Sri Rumini (1995) yang dikutif dari Muzakki (2012: 1617), ada beberapa elemen penting yang menggambarkan ciri-ciri belajar :

a. Dalam belajar ada perubahan tingkah laku, baik tingkah laku yang dapat diamati maupun tingkah laku yang tidak dapat diamati secara langsung.

b. Dalam belajar, perubahan tingkah laku meliputi tingkah laku kognitif, afektif, psikomotor dan campuran.

c. Dalam belajar, perubahan tingkah laku yang terjadi karena mukjizat, hipnosa, hal-hal yang gaib, proses pertumbuhan, kematangan, penyakit 
ataupun kerusakan fisik, tidak dianggap sebagai hasil belajar.

d. Dalam belajar, perubahan tingkah laku menjadi sesuatu yang relatif menetap. Bila seseorang dengan belajar menjadi dapat membaca, maka kemampuan membaca tersebut akan tetap dimilliiki.

e. Belajar merupakan suatu proses usaha, yang artinya belajar berlangsung dalam kurun waktu cukup lama. Hasil belajar yang berupa tingkah laku kadang-kadang dapat diamati, tetapi proses belajar itu sendiri tidak dapat diamati secara langsung.

f. Belajar terjadi karena ada interaksi dengan lingkungan.

\section{Metode Diskusi Kelompok Kecil}

Diskusi kelompok kecil

menurut I.G.A.K. Wardani dan Siti Julaeha (IDIK 4307: 22) menjelaskan bahwa diskusi kelompok keci adalah salah satu bentuk kegiatan pembelajaran yang penggunaannya cukup sering diperlukan dengan ciriciri: 1) melibatkan 3-9 orang peserta; 2) berlangsung dalam situasi tatap muka yang informal, artinya setiap anggoa dapat berkomunikasi langsung dengan anggota lainnya; 3) mempunyai tujuan yang dicapai dengan kerjasama antar anggota, serta 4) berlangsung menurut proses yang sistematis.

Menurut Paizaluddin dan Ermalinda (2012: 215) metode diskusi merupakan cara penyajian pelajaran dimana siswa dihadapkan kepada suatu masalah yang bisa berupa pernyataan atau pertanyaan yang bersifat problematik untuk dibahas dan dipecahkan bersama.

Sementara menurut H. Martinis Yamin (2013: 156) metode diskusi merupakan interaksi antara peserta didik dan peserta didik atau peserta didik dengan guru untuk menganalisis, memecahkan masalah, menggali atau memperdebatkan topik atau permasalahan tertentu. Selanjutnya dijelaskan bahwa metode ini digunakan apabila: a) disediakan bahan, topik atau masalah yang akan didiskusikan, b) disebutkan pokok-pokok masalah yang akan didiskusikan, c) ada penguatan agar peserta didik menjelaskan, menganalisis, meringkaskan, d) guru membimbing diskusi, tidak menceramahkan, e) guru harus sabar terhadap kelompok yang lamban dalam mendiskusikan sesuatu, f) guru harus waspada terhadap kelompok yang kebingungan atau berjalan dengan tidak menentu, g) guru harus melatih peserta didik agar menghargai pendapat orang lain. Sedangkan kelemahan metode diskusi adalah: a) menyita waktu lama, b) mempersyaratkan peserta didik memiliki latar belakang yang cukup tentang topik atau masalah yang didiskusikan, c) metode ini tidak dapat digunakan pada tahap awal proses belajar bila peserta didik baru diperkenalkan kepada bahan pembelajaran baru, d) apatis bagi peserta didik yang tidak terbiasa berbicara dalam forum.

Metode diskusi merupakan metode atau cara yang dapat diupayakan untuk meningkatkan kerjasama antarsiswa, saling membantu, saling pengertian antara mereka dengan memberi suatu masalah untuk didiskusikan. Dalam kegiatan tersebut mereka dapat saling tukar pengalaman, saling tukar informasi, sehingga semua siswa dapat aktif dalam belajar.

\section{Pembelajaran Matematika}

Pembelajaran Matematika bagi para siswa merupakan pembentukan pola pikir dalam pemahaman suatu pengertian maupun dalam penalaran 
suatu hubungan diantara pengertianpengertian itu. Dalam pembelajaran matematika, para siswa dibiasakan untuk memperoleh pemahaman melalui pengalaman tentang sifat-sifat yang dimiliki dan yang tidak dimiliki dari sekumpulan objek (abstraksi). Siswa diberi pengalaman menggunakan matematika sebagai alat untuk memahami atau menyampaikan informasi misalnya melalui persamaanpersamaan, atau tabel-tabel dalam model-model matematika yang merupakan penyederhanaan dari soalsoal cerita atau soalsoal uraian matematika lainnya NCTM (National Coucil of Teachers of Mathematics) merekomendasikan 4 (empat) prinsip pembelajaran matematika, yaitu : a. Matematika sebagai pemecahan masalah. b. Matematika sebagai penalaran. c. Matematika sebagai komunikasi, dan d. Matematika sebagai hubungan (Erman Suherman, 2003:298).

Matematika perlu diberikan kepada siswa untuk membekali mereka dengan kemampuan berpikir logis, analitis, sistematis, kritis, dan kreatif serta kemampuan bekerjasama. Standar Isi dan Standar Kompetensi Lulusan (Depdiknas, 2006:346) menyebutkan pemberian mata pelajaran matematika bertujuan agar peserta didik memiliki kemampuan sebagai berikut.

a. Memahami konsep matematika, menjelaskan keterkaitan antara konsep dan mengaplikasi konsep atau logaritma secara luwes, akurat, efisien dan tepat dalam pemecahan masalah.

b. Menggunakan penalaran pada pola dan sifat, melakukan manipulasi matematika dalam membuat generalisasi, menyusun bukti, atau menjelaskan gagasan dan pernyataan matematika. c. Memecahkan masalah yang meliputi kemampuan memahami masalah, merancang model matematika, menyelesaikan model, dan menafsirkan solusi yang diperoleh.

d. Mengkomunikasikan gagasan dengan simbol, tabel, diagram, atau media lain untuk menjelaskan keadaan/masalah.

e. Memiliki sifat menghargai kegunaan matematika dalam kehidupan, yaitu: memiliki rasa ingin tahu, perhatian, dan minat dalam pelajaran matematika serta sikap ulet dan percaya diri dalam pemecahan masalah.

Tujuan umum adalah memberikan penekanan pada keterampilan dalam penerapan matematika, baik dalam kehidupan sehari-hari maupun dalam membantu mempelajari ilmu pengetahuan lainnya.

Fungsi mata pelajaran matematika sebagai: alat, pola pikirdan ilmu atau pengetahuan (Erman Suherman, 2003:56). Pembelajaran matematika di sekolah menjadikan guru sadar akan perannya sebagai motivator dan pembimbing siswa dalam pembelajaran matematika di sekolah

\section{HASIL PENELITIAN DAN PEMBAHASAN HASIL PENELITIAN \\ Deskripsi Awal}

Gambaran yang diperoleh dari kegiatan awal adalah di satu pihak tidak berhasilnya guru dalam melaksanakan pembelajaran mengingat kegiatan yang dilakukan belum mengikuti pendapat para ahli pendidikan. Metode yang digunakan masih tradisional, masih yang biasa dilakukan sehari-hari misalnya penggunaan metode diskusi kelompok kecil masih satu arah atau paling tinggi 
dua rah, dan belum giat menggunakan metode diskusi kelompok kecil. Model yang digunakan masih juga menggunakan model yang bisa dilakukan sehari-hari, belum mengikuti model yang digunakan para ahli pendidikan. Akibatnya nilai anak masih cukup rendah, hanya 10 orang dari 40 anak di kelas VI semester II SD Negeri 2 Peguyangan tahun pelajaran 2016/2017 mampu memperoleh ketuntasan belajar sedangkan yang lainnya yaitu 30 orang $(75,00 \%)$ masih berada pada kriteria di bawah KKM. Di lain pihak yaitu di pihak siswa, hal ini merupakan ciri bahwa sebagian besar anak masih membutuhkan bimbingan dan latihan serius untuk dapat meningkatkan perkembangan diri mereka dari kebiasaan sehari-hari yang niat belajarnya rendah.

\section{Deskripsi Siklus I}

\section{Perencanaan I}

Perencanaan pada Siklus I disusun sedemikian rupa untuk membantu peserta didik dalam meningkatkan prestasi belajar mereka. Adapun persiapan yang direncanakan yaitu :

1. Menyusun rencana kegiatan, menyusun jadwal.

2. Menyusun RPP

3. Berkonsultasi dengan teman-teman guru membicarakan alat-alat peraga, bahan-bahan yang bisa membantu proses pembelajaran.

4. Merencanakan model pembelajaran yang paling tepat dengan menyiapkan media-media yang diperlukan.

5. Menyusun format penilaian.

6. Membuat bahan-bahan pendukung pembelajaran lainnya seperti Buku paket, LKS dan RPP.

7. Merancang skenario pembelajaran. Pelaksanaan I
1. Pada saat akan memasuki kelas, semua persiapan-persiapan ajar telah dibawa.

2. Memasuki kelas guru memberi salam pada anak-anak.

3. Anak-anak diatur sedemikian rupa agar mendapat ruang yang cukup untuk belajar.

4. Mengelola kelas sambil membimbing mereka dengan memperhatikan kebutuhan setiap anak.

Observasi I

Hasil observasi I terhadap keberhasilan pelaksanaan proses Refleksi Siklus I

Analisis

Pada siklus I, ada 12 orang $(30,0 \%)$ yang memperoleh nilai di atas KKM, ada 6 orang $(15,0 \%)$ yang memperoleh nilai sama dengan KKM dan 22 orang $(55,0 \%)$ yang memperoleh nilai di bawah KKM. Analisis kuantitatif siklus I sebagai berikut:

1. Rata-rata (mean)

Rata-rata (mean) dihitung dengan:

$\frac{\text { Jumlah nilai }}{\text { Jumlah siswa }}=\frac{2.715}{40}=67,87$

2. Median

Menghitung median dilakukan dengan cara mengurut data/nilai siswa dari yang terkecil sampai terbesar.Setelah diurut apabila jumlah data ganjil maka mediannya adalah data yang ditengah.Kalau jumlahnya genap maka dua data yang di tengah dijumlahkan dibagi 2 (dua). Untuk median yang diperoleh dari data siklus I dengan menggunakan cara tersebut adalah: 65

3. Modus

Menentukan modus dari hasi penelitian yang dilakukan tidaklah begitu sulit.Modus merupakan angka yang terbanyak muncul dari data yang diperoleh. Dalam penelitian ini modus yang diperoleh adalah 60,00 
Untuk persiapan penyajian dalam bentuk grafik maka hal-hal berikut dihitung terlebih dahulu.

Banyak kelas (K)

$=1+3,3 \times \log (\mathrm{N})$

$=1+3,3 \times \log 40$

$=1+3,3 \times 1,6$

$=1+5,28=6,28 \rightarrow 6$

Rentang kelas (r)

$=$ skor maksimum - skor minimum

$=80-60=20$

Panjang kelas interval (i) $=\frac{r}{K}=\frac{20}{6}=$ $3,33 \rightarrow 3$

\section{Sintesis}

Sintesis dari hasil penelitian pada siklus I dapat disampaikan : dari 40 anak yang diteliti, sudah 45,0\% anak sudah sesuai harapan indikator dengan mendapat penilaian di atas KKM. Hasil tersebut menunjukkan bahwa anak mampu meningkatkan prestasi belajar mereka dalam mata pelajaran Matemtika . Ada 15,0\% mencapai nilai KKM artinya bahwa mereka sudah berhasil namun masih pada tingkat keberhasilan minimal, belum optimal. Selebihnya yang jumlahnya $55,0 \%$ belum mencapai tingkat keberhasilan sesuai harapan, artinya mereka masih harus lebih giat belajar, guru harus lebih giat membimbing. Dari data pencapaian siklus I ini dapat diberikan sintesis bahwa pencapaian peningkatan prestasi belajar anak belum sesuai harapan indikator keberhasilan penelitian yang diusulkan yaitu $80,00 \%$ atau lebih anak mencapai tingkat keberhasilan sesuai dan melebihi KKM.

Penilaian Siklus I
Kekurangan-kekurangan yang ditemukan untuk penggunaan metode diskusi kelompok kecil pada mata pelajaran matematika secara mendalam pada anak didik dibutuhkan waktu yang lebih lama lagi, sebab sebagian anak belum memiliki dasar-dasar pengetahuan tentang konsep tersebut, keterampilan anak dalam melakukan hal-hal yang diminta masih belum terlatih, masih banyak anak yang belum terbiasa melakukan hal tersebut. Kelebihan yang ada adalah: alat peraga telah disiapkan dengan baik agar mendukung proses pembelajaran, pengelolaan kelas sudah diupayakan dan bimbingan terhadap anak juga sudah dilakukan dengan maksimal dan teori-teori yang ada sudah digunakan dalam melaksanakan proses pembelajaran.

Semua kekurangan yang telah disampaikan itu akan dibenahi pada siklus selanjutnya. Demikian penilaian yang bisa disampaikan untuk memberikan gambaran terhadap keberadaan semua tindakan yang telah dilakukan.

\section{Deskripsi Siklus II}

Perencanaan II

Mengacu pada hasil analisis dan penilaian pelaksanaan siklus I, penulis melakukan hal-hal berikut dalam perencanaan :

1. Mencek jadwal yang sudah dibuat pada perencanaan awal

2. Mencek kekurangan-kekurangan sebelumnya

3. Berkonsultasi dengan teman-teman guru tentang metode diskusi kelompok kecil

4. Menyusun RPP mengikuti alur metode diskusi kelompok kecil

Pelaksanaan II

a. Mengajar dengan membawa semua persiapan-persiapan ajar. 
b. Mengatur anak-anak agar duduk dengan rapi dan ada ruang yang cukup bagi anak-anak untuk mengikuti proses dengan baik.

c. Pada saat membimbing, penulis mengisi blanko observasi yang telah dibuat untuk memberi penilaian terhadap siswa-siswa yang afektif dalam belajar.

Pengamatan/Observasi II

Hasil pengamatan/observasi II sebagai berikut:

\section{Refleksi II}

Analisis

Pada siklus II perolehan hasil peningkatan prestasi belajar siswa kelas VI semester II SD Negeri 2 Peguyangan tahun pelajaran 2016/2017 adalah dari 40 orang anak yang diteliti, ada 37 orang $(92,50 \%)$ yang memperoleh nilai di atas KKM yang artinya mereka sudah meningkat melebihi target yang ditetapkan, ada 2 orang $(5,00 \%)$ yang memperoleh nilai rata-rata KKM yang artinya anak sudah giat melakukan tetapi baru mampu mencapai keberhasilan minimal. Selain itu masih ada 1 anak $(2,50 \%)$ yang tertinggal namun jumlah ini cukup rendah. Walaupun demikian peneliti sebagai guru harus mengupayakan jalan untuk memperbaiki tingkat kemampuan anak-anak tersebut. Dari analisis kualitatif sudah disampaikan secara singkat, selanjutnya diberikan analisis kuantitatifnya menggunakan data yang diperoleh adalah dalam bentuk angka sebagai berikut :

1. Rata-rata (mean)

Rata-rata (mean) dihitung dengan:

$\frac{\text { Jumlah nilai }}{\text { Jumlah siswa }}=\frac{2964}{40}=74,10$

2. Median

Menghitung median dilakukan dengan caramengurut data/nilai siswa dari yang terkecil sampai
terbesar.Setelah diurut apabila jumlah data ganjil maka mediannya adalah data yang ditengah.Kalau jumlahnya genap maka dua data yang di tengah dijumlahkan dibagi 2 (dua). Untuk median yang diperoleh dari data siklus I dengan menggunakan cara tersebut adalah: 76,00

4. Modus

Menentukan modus dari hasi penelitian yang dilakukan tidaklah begitu sulit.Modus merupakan angka yang terbanyak muncul dari data yang diperoleh. Dalam penelitian ini modus yang diperoleh adalah 75,00.

Untuk persiapan penyajian dalam bentuk grafik maka hal-hal berikut dihitung terlebih dahulu.

1. Banyak kelas $(\mathrm{K})$

$$
\begin{aligned}
& =1+3,3 \times \log (\mathrm{N}) \\
& =1+3,3 \times \log 40 \\
& =1+3,3 \times 1,6 \\
& =1+5,28=6,28 \rightarrow 6
\end{aligned}
$$

2. Rentang kelas (r)

$$
=\text { skor maksimum }- \text { skor }
$$
minimum

$$
\begin{aligned}
& =83-69 \\
& =14
\end{aligned}
$$

3. Panjang kelas interval (i)

$$
=\frac{r}{K}=\frac{14}{6}=2,33 \rightarrow 3
$$

\section{Sintesis}

Peningkatan nilai siswa dari data siklus I yang baru mencapai ratarata 69,87 dengan ketuntasan belajar 
45,0\% sudah mampu ditingkatkan menjadi rata-rata 74,10 dengan ketuntasan belajar 97,50\%. data tersebut artinya hasil yang diperoleh sudah sesuai dengan harapan. Dari perkembangan tersebut diketahui hampir semua siswa sudah meningkat prestasi belajarnya. Dari semua data yang sudah diperoleh tersebut dapat diberikan sintesis lanjutan bahwa sebagian besar siswa sudah mampu meningkatkan prestasi belajarnya, proses pembelajaran yang dilakukan guru sudah berhasil, inovasi sudah berjalan baik, bimbingan guru sudah maksimal, arahan yang dilakukannya anak-anak giat belajar juga sudah mampu dilakukan dengan baik. Hal tersebut berarti indikator keberhasilan penelitian pada siswa SD Negeri 2 Peguyangan sudah terpenuhi.

\section{Penilaian Siklus II}

Penilaian yang dapat diberikan terhadap pelaksanaan Siklus II ini yaitu pembelajaran menggunakan metode diskusi kelompok kecil telah tuntas dapat dilaksanakan. Semua kekurangan-kekurangan yang ada sudah diperbaiki pada siklus ini, sehingga tidak ada yang masih perlu dipaksakan oleh peneliti bahwa penelitian ini tidak perlu dilanjutkan lagi ke siklus berikutnya.

\section{PEMBAHASAN}

Pembahasan hasil yang didapat dari data awal. Dari data awal diperoleh kenyataan bahwa hanya ada 75 orang $(12,5 \%)$ yang memperoleh nilai di atas KKM dan 5 orang $(12,50$ $\%$ yang memperoleh nilai sama dengan KKM sedangkan yang lainnya yang berjumlah 30 orang $(75,00 \%)$ memperoleh nilai di bawah KKM. Jadi, masih banyak siswa yang memerlukan bantuan guru dan termasuk bantuan orang tua mereka untuk membiasakan anak melakukan hal-hal yang bermanfaat bagi mereka, baik sekarang maupun setelah dewasa nanti. Melalui observasi awal yang dilakukan peneliti, didapati bahwa kelemahan yang ada dikarenakan belum terjadi pembiasaan perilaku pada diri anak untuk giat belajar sehingga menjadi tugas peneliti untuk membuat mereka terbiasa melakukan kegiatan-kegiatan yang bermanfaat melalui pembiasaan.

Pembahasan hasil yang didapat dari data siklus I. Pada Siklus I diperoleh data dari hasil observasi adalah ada 12 orang $(30,0 \%)$ yang memperoleh nilai di atas KKM, ada 6 orang $(15,0 \%)$ yang memperoleh nilai sama dengan KKM dan 22 orang $(55,0 \%)$ yang memperoleh nilai di bawah KKM. Data tersebut menunjukkan bahwa keberhasilan yang dicapai pada siklus I belum memenuhi indikator keberhasilan yang dipersyaratkan. Karena itu penelitian harus terus dilanjutkan ke siklus berikutnya. Hal yang masih menjadi kendala adalah belum adanya penghargaan yang diberikan kepada mereka yang telah mencapai kategori tuntas. Di samping itu untuk menanamkan kebiasaan giat belajar tidak bisa sehari dua hari tapi dibutuhkan waktu yang cukup lama agar kegiatan bermanfaat dapat dilakukan secara spontan dan otomatis oleh anak. Misalnya: sekali dua kali anak masih disuruh untuk giat berlatih, anak disuruh menulis pertanyaanpertanyaan untuk diajukan pada guru dan teman-temannya sebagai bahan perdebatan. Dengan cara tersebut dan akibat akhirnya mereka akan terbiasa dengan keadaan belajar. Tentu hal tersebut harus dilakukan dengan giat dan berulang-ulang. Hal inilah yang telah dilakukan pada siklus I untuk menopang peningkatan kemampuan belajar anak. 
Pembahasan hasil yang didapat dari data siklus II. Melihat semua kendala yang masih terjadi pada siklus I maka pada siklus II ini peneliti telah giat memperbaiki perencanaan yang ada agar dalam pelaksanaannya di kelas nanti dapat berjalan lancar dan sesuai harapan. Yang dilakukan adalah perubahan gaya mengajar. Sebelumnya, dengan betul-betul giat melakukan proses pembelajaran. Di samping inovasi, validasi sudah dilakukan dengan menyodorkan pada teman-teman sejawat tes yang akan diberikan serta mencocokkan materi dengan indikator-indikator yang akan diajar. Usaha ini akan membantu reabilitas data yang akan dihasilkan setelah pelaksanaan tindakan.

Kematangan siswa dalam belajar sudah diupayakan dengan pembiasaan-pembiasaan, siswa-siswa yang belum aktif dipecahkan dengan memberi pertanyaan-pertanyaan yang berhubungan dengan materi yang diajar ditambah dengan semua anak disuruh membuat masing-masing sebuah pertanyaan yang akan disodorkan sebagai bahan berdiskusi dan berargumentasi. Teori-teori tentang model pembelajaran giat dipelajari sebagai upaya trianggulasi. Dengan semua kegiatan itu dilakukan dengan seksama dan sungguh-sungguh melalui arahan-arahan, penguatan-penguatan, bimbingan-bimbingan, pembiasaanpembiasaan sehingga tercermin peningkatan hasil sesuai harapan. Setelah pelaksanaan tindakan di siklus II yang sudah diupayakan secara masimal, ternyata hasil yang diperoleh sudah meningkat yaitu ada 37 orang $(92,50 \%)$ yang memperoleh nilai di atas KKM, ada 2 orang $(5,00 \%)$ yang memperoleh nilai rata-rata KKM dan 1 orang $(2,50 \%)$ yang memperoleh nilai di bawah KKM. Dengan data tersebut dapatlah dideskripsikan bahwa peningkatan hasil sudah sesuai harapan yang dituntut. Data tersebut mampu membuktikan keberhasilan tujuan penelitian sehingga penelitian sudah dianggap cukup dan tidak diteruskan.

\section{SIMPULAN}

Simpulan yang dapat disampaikan berdasar semua temuan hasil penelitian adalah bahwa metode diskusi kelompok kecil yang telah dilaksanakan mampu menjawab rumusan masalah penelitian ini serta mampu membuktikan bahwa tujuan penelitian ini sudah dapat dicapai. Sebagai bukti atas pencapaian hal tersebut adalah:

a) Dari data awal ada 30 anak mendapat nilai di bawah KKM dan pada siklus I menurun menjadi 22 anak dan siklus II hanya 1 anak mendapat nilai di bawah KKM.

b) Nilai rata-rata awal 64,98 naik menjadi 67,87 pada siklus I dan pada siklus II naik menjadi 74,10

c) Dari data awal anak yang tuntas hanya 10 orang sedangkan pada siklus I menjadi lebih banyak yaitu 18 anak dan pada siklus II menjadi cukup banyak yaitu 39 anak.

d) Presentase yang diperoleh meningkat keberhasilannya. Dari data awal baru 25,00\% yang berhasil, pada siklus I meningkat menjadi $45,0 \%$ dan pada siklus II naik menjadi $97,50 \%$.

Dari data tersebut diatas maka dapat disimpulkan bahwa penggunaan metode diskusi kelompok kecil dapat meningkatkan prestasi belajar matematika siswa kelas VI semester II SD Negeri 2 Peguyangan Tahun pelajaran 2016/2017.

\section{DAFTAR PUSTAKA}


Abin Syamsudin. 2009. Psikologi Kependidikan. Bandung : PT. Remaja Rosdakarya.

Arikunto, Suharsimi; Suhardjono; Supardi. 2006. Penelitian Tindakan Kelas. Jakarta: PT Bumi Aksara.

Bhakti, Ahmad Haris. 2009. Tesis. Pengaruh Strategi Pembelajaran Kooperatif Tipe STAD ( Student Team Achievement Division ) Dan Jigsaw Terhadap Prestasi Belajar Pendidikan Kewarganegaraan Ditinjau Dari Minat Belajar Siswa SMP Negeri Di Kecamatan Ngawi. Program Studi Teknologi Pendidikan. Program Pascasarjana Universitas Sebelas Maret. Surakarta.

Degeng, I N.S. 2001.Landasan dan Wawasan Kependidikan. Malang: $\quad$ Lembaga Pengembangan dan Pendidikan (LP3) Universitas Negeri Malang.
Muzakki. 2012. Thesis. Hubungan Antara Penggunaan Media Pembelajaran Dan Kreativitas Mengajar Guru Dengan Prestasi Belajar Menggunakan Peralatan Kantor Anak kelas X SMK N 1 Jogonalan Tahun Ajaran 2011/2012. Universitas Negeri Yogyakarta. eprints.uny.ac.id/8915/

Paizaluddin dan Ermalinda. 2013. Penelitian Tindakan Kelas. Bandung: Alfabeta.

Peter Salim, 1995. Kamus Bahasa Indonesia Kontemporer, Jakarta: Balai Pustaka

Sumiati dan Asra. 2007. Metode Pembelajaran. Diadakan oleh Direktorat Jenderal Peningkatan Mutu Pendidikan dan Tenaga Kependidikan.Departemen Pendidikan dan Kebudayaan. Penerbit: CV Wacana Prima. Bandung

Tirtonegoro, Sutratinah. 2001. Penelitian hasil belajar mengajar. Surabaya: Usaha Nasional. 